\title{
The Effect of Eugenol and Eugenol-Containing Root Canal Sealers on the Microhardness of Human Dentin
}

Glenn M. Biven

Loyola University Chicago

Follow this and additional works at: https://ecommons.luc.edu/luc_theses

Part of the Dentistry Commons

\section{Recommended Citation}

Biven, Glenn M., "The Effect of Eugenol and Eugenol-Containing Root Canal Sealers on the Microhardness of Human Dentin" (1971). Master's Theses. 2536.

https://ecommons.luc.edu/luc_theses/2536

This Thesis is brought to you for free and open access by the Theses and Dissertations at Loyola eCommons. It has been accepted for inclusion in Master's Theses by an authorized administrator of Loyola eCommons. For more information, please contact ecommons@luc.edu. c) (i) ()

This work is licensed under a Creative Commons Attribution-Noncommercial-No Derivative Works 3.0 License. Copyright (c) 1971 Glenn M. Biven 
THE EFFECT OP EUGENOL AND EUGENOL-CONTAINING ROOT CANAL SEALERS ON THE MICROHARDNESS OP HUYAN DENTIN

by

Glemn.H. BIVen, B.S., D.D.S.

A Thesis Submitted to the Faculty of the Graduate School of Loyola University in Partial Fulfiliment of the foqulrement for the Degree of Haster of Science

May, 1971 


\section{CURRICULUM VITAE}

Glenn Mamo Biven was born in Honolulu. Hawa11 on the 4 th day of July 1935. He attended Iolani School in Honolulu, and graduated in June, 1954.

After four years at Creighton University College of Arts and Sclences, Omaha, Nebraska, he recelved his Bachelor of Sclence degree in June, 1958, and entered Creighton University School of Dentiatry that fall. He graduated from the dental school in June, 1962, with the degree of Doctor of Dental Surgery.

Following graduation from dental school, he entered the United States Army Dental Corps and has served at Fort Lewis, Washington; Seoul, Korea; and Fort Sam Houston, Texas. In 1969. he was accepted to the Graduate School, Loyola University matriculating in the Department of Oral Blology, and to the Department of Endodontics as a resident.

He 18 a career officer in the United States Army with the rank of Major. 


\section{DEDICATION}

To my wife, Luc1lle, and my children, Petrina and Gentry, whose loyal support and sacrifices have contributed to my coals.

To my mother, Carnation K. Biven, for her love, encouragement, and inspiration in making this all possible. 


\section{ACKNOWLEDGEMENTS}

It $1 \mathrm{~s}$ with sincere appreciation that I thank my research advisor Mahendra S. Bapna. Ph.D. for his untiring guidance and encouragement in the preparation of this thesis.

I am especially grateful to Michael A. Heuer, D.D.S.. M.S., for proposing certain ldeas which culminated in the concept for this investigation. His undaunted efforts and assistance is accepted with deepest gratitude.

My gratitude to Marshall H. Smulson, D.D.S., Cha1rman, Depertment of Endodont1cs, and the members of the faculty of the department for their encouragement and immeasurable contributions to my education.

I am grateful to my superior officers in the United States Army Dental Corps wo made possible my attendance to this institution of advanced education programs. 
TABLE OF CONTENTS

CHAPTER

Page

I.

INTRODUCTION

II.

REVIEW OF THE LITERATURE ........... 5

A. Zinc oxide and Eugenol Cements

B. Root Canal Cements or Sealers

III. METHODS AND MATERIALS ............... 24

A. Selection and Preparation of specimen

B. Method of Microhardness Evaluation

C. Materials Utilized to Affect Dentin

D. Procedure for Determination of Values

IV. RESULTS ........................... 34

v. DISCUSSION .................... 47

vI. $\quad$ SUMMARY ...................... 55

REFERENCES ...................... 56 


\section{LIST OF TABIES}

Table

Page

1 Mean Comparative Microhardness Determinations (KHN) of Control Teeth .... 35

2 Typlcal Rows of Microhardness Values ut1l1zing Eugenol ............. 37

3 Mean Comparative Microhardness Determinations (KHN) ut111zing Eugenol .... 38

4 Typical Rows of Microhardness Values ut1lizing Proco-Sol Rad1opaque

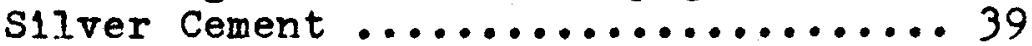

5 Mean Comparative Microhardness Determinations (KHN) utilizing Proco-Sol Radlopaque Silver Cement ......... 40

Typlcal Rows of Microhardness Values utilizing Kerr Root Canal Sealer .... 42

7 Mean Comparat1ve Microhardness Determinations (KHN) utilizing Kerr Boot Canal sealer ..................4 43

8 Summary of Mean Comparative Microhardness Values (KHN) of Human Dentin due to Eugenol and Eugenol-containing Root Canal Sealers ........... 45

9 Statistical Analysis Utilizing the t-Test Evaluation of Microhardness Increase of Affected Dentin ........44 
CHA PTER 1

\section{INTRODUCTION}

Through the years, men especlally versed in the fleld of endodontics have been concerned with the perplexity of exactly obliterating a root canal. It is a most important phase in endodont1c therapy that the root canal space be entirely filled with some inert and hermetically sealing agent to attain success.

Ingle $e^{1}$ simply states that: "The primary objective of operative endodontics must be the development of a fluid-tight seal at the apical foramen, and total obliteration of the root canal space." Th1s 1dea of a totally obliterating and hermetlcally sealing the root canal has been expressed by many authors $2 \cdot 3,4,5,6$ in a number of ways.

Grossman ${ }^{6}$ has characterized the various acceptable fillIng materlals as cements, pastes, plastics, and solids.

Currently, the methods most frequentiy employed to 1111 root canals involies the combination of a bulk filling material consisting of a rigid or plastic point used in conjunction with a cement or sealer. Whether or not the cement or sealer Itself would bring about the hermetic seal is not a matter of 
confecture, for it is the combination that properly fills the root canel.

The requirements and characteristics of a good root canal cement has been enumerated by Grossman 6 and sommer et al. 9 as follows:

1) It should be tacky when mixed to provide good adhesion.

2) It should provide a hermetic seal.

3) It should be radiopaque.

4) It should be tissue tolerant.

5) It should be bacteriostatic.

6) It should not shrink.

7) It should set slowly.

8) It should be insoluble in tissue fluids.

9) The powder particles should be very fine for easy mixing.

10) It should be soluble in a common solvent for easy removal if necessary.

The 1deal root canal cement or sealer that w11l satisfy all these requirements has yet to be formulated. For the varlous commercially avallable root canal sealers, there are no set standards of quality or performance with which they must comply. Root canal sealers are currently outside the 
scope of the Food and Drug Administration of the Federal Government and do not come under the auspices of etther the Council on Dental Therapeutics or the Bureau of Materials and Devices of the American Dental Association, although the latter body ma at some future date concern 1 tself with the physical properties of root canal sealer, if not their histopathological potentlals. In general, very little basic research preceeds the introduction of a root canal sealer into the dental market place, and it is up to the consumer to discover the discrepancies between promotional petter and clinical performance, and then attempt to compensate for shortcomings in the different products that they desire to utilize. The maforlty of the studies of root canal sealers deal with connect1ve tissue responses to them, and a Iimited number of the investigations have been concerned with the physical properties of root canal sealers. This study will undertake the investigation of an unknown property of root canal sealers. It is the purpose of this study to determine the effect(s) that eugenol and eugenol-containing root canal sealers have on sound dentinal surfaces. By means of comparative microhardnesses of pretreated and posttreated dentinal surfaces of the root, the effects of varlous sealers will be measured by determinating the alteration these materials produce in the 
hardness of dentin. 
CHAPTER 2

\section{LITERATURE REVIEW}

During the past two decades, tremendous strides have been made in the scientific approach to endodont1cs. At the second International Conference on Endodont1cs held in Philadelphia In 1958, Ingle and LeV1ne ${ }^{10}$ demonstrated the fact that there was a total absence of true formulation of endodontic instruments and flling materials alike. The analysis of their reported data led the way to the resolution of some of the major problems relating to the uniformity of sizing in endodont1c instruments and solid core filling materials. We are currently approaching a point of ultramodern refinement of the design and construction of the instruments required in the practice of endodontics, but we have yet to begin resolving the problems relating to endodontic filling materials.

The clinical methods of preparing the pulpal space for recelving a root canal filling material, the method of bacterial control, and the method of obliterating the root canal are many and varied, and are justiflably so. As Grossman ${ }^{11}$ reminds us, the fact that there are several methods of filling 
canals is in itself an indication that no one method w1Il suffice in all cases. The canals may be wide or narrow, Iong or short, round or ovold, straight or curved, and all combinations thereof. The methods used in arriving at a good root fill may be considered immaterial provided the pulpal space is totally sealed and obliterated.

There have been many materials, I1terally hundreds, used in the attempt to find the root canal filling materlal ideal for all clrcumstances. Grossman ${ }^{6}$ gives a partial 11 st of these that runs the gamut from amalgam to wood. Coolidge and Kesel ${ }^{13}$ groups the root canal fllling materials into:

1) Antiseptics combined with a rehicle.

2) Cements and plastic materials.

3) Gutta-percha used separately or in combination with other substances.

4) Metals.

Grossman has stated in $1963^{14}$ and in $1966^{6}$ that the next great advance in endodontics will be in the fleld of root canal fliling: a more simple and accurate fliling material. Since that time, there have been no major advances in this area. The use of a solid or plastic point in combination with a cementing material is by far the most popular means of obliterating a root canal at present (1971). Whether the more un1- 
versaliy used gutta-percha cone or the less acceptable silver cone is used. It is felt by most practitioners that these points alone do not adequately seal a root canal and they must be used in confunction with a sealer or cement.

The need for a root canal sealer or cement can be clearly shown when one looks at cross-sections of the roots of teeth prepared for filling. The normal irregularities of the pulp canal are almost never completely oliminated during the canal preparation. Haga ${ }^{16}$ in 1967 pointed out that at $2 \mathrm{~mm}$. and $6 \mathrm{~mm}$. levels from the apex, the root canal files cut only on three walls of many of the root canals he studied. Gutlerrez and Garcia 17 demonstrated through microscoplc and macroscopic investigations that a high incidence of prolongations of the root canal, closely resembling the fins of a flsh, were never touched by the root canal instrumentation. The occurrence of transverse or horizontal intra-radicular canals may persist and may interconnect the normally occurring central root canals at varying levels of the tooth. Accessory canals also occur at different levels of the root, and they communicate with the periodontal 11gament. Employing sealers or cements facilitates the complete obliteration of these internal 1rregularities in pulp canal anatomy found in many teeth. The history of root canal cements goes back to 1856 , when 
Sorel 11,13 introduced a cement consisting of a saturated solution of marnesium chloride and magneslum oxide. In 1883, sir John Tomes ${ }^{11}$ recommended using paraffin as a root canal filler. Parafín was easy to use, but it tended to shrink. In 1920 , Brady ${ }^{18}$ used a neo-balsam sealing agent which he claimed neither shrunk nor gbsorbed molsture. In 1929. Grove ${ }^{19}$ employed the use of "neutrolite", a carbolated resin which he described as being an impervious liquid sealer which hardens at body temperature. Also in 1929. Buckley ${ }^{20}$ utilized a material called "dentinold", a physical mixture of calcium phosphate, barlum sulfate, with resins and antiseptics added to provide more plasticity when used in combination with lead points. In 1931, Rickert ${ }^{21}$ formulated a zinc oxide-eugenol cement which is still arailable commercially, and widely used In clinical practice. In 1936, Grossman 22 developed a cement consisting of zinc oxide, Staybelite resin, and silver. Both the Grossman and Rickert sealers met most of the postulated requirements of the ideal root crnal sealer. Schmitt 23 introduced a polyrinyl resin, Dlaket, in Europe in 1951. Waechter 24 reported Diaket was a keto-complex in which the neutral organic agents reacted with basic salts or basic metal oxides. These polyketones united with the metallic substances in the sealer to develop cyclic complexes which are insoluble in water, but 
soluble in spectal organic solvents and in chloroform.

The formula for wach's compound, a root canal sealer, was published in $1955^{25}$ and again in 1958 26 , although it had been in use for over 30 years. This cement 18 essentialiy a zinc oxide and eugenol mixture with most of the eugenol replaced by the Canada balsam. In 1957, Schroeder 27 demonstrated that $A B-26$, an epoxy resin. 18 well tolerated by the perlapical t1ssues, and has good adhesive properties, contracting only sliehtly while hardenlag. Then in 1958. Grossman 28 dereloped a nonstaining root canal cement. This cement is also a zinc oxide-eugenol mixture that has been modifled to slightly retard the setting time. Although reasons were published for the varlous additives, these reasons were not substanclated by experimental evidence.

The present day root canal cements are composed of varlous substances which when first combined are soft and adhesive, but later become hard as the result of chemical reactions between certain specific substances and in addition to the $108 \mathrm{~s}$ of excess liquid portions by evaporation and side reactions with other substances extraneous to the cement 1tself. Nielson 29 stated that in order for a root canal cement be efrective, it must have a reasonable coefficlent of expansion. It should also be impenetrable by bacteria and be resistant to both 
physical and chemical influences, while in situ.

A. Zinc oxide and Eugenol Cements

Eugenol is an aromatic oll which has a methoxy group ortho to a phenolic hydroxy group. It is the essential constituent of oll of cloves, cinnamon, and other spices. It is also called eugenic acid or caryophilic acid.

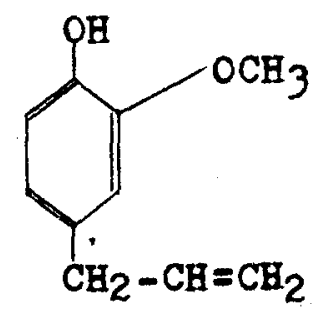

Eugenol

Molnar 30 reports that oll of cloves had been used for the treatment of dental caries as early as the 16 th century, but it was not unt1l 1873, that Chr1sholm 31 described the preparation of zinc oxide-oll of cloves. Since eugenol makes up $85 \%$ of o1l of cloves, and it alone is the agent responsible for the therapeut1c effects, it has been substituted in dental preparations for oll of cloves.

The nature of the setting reaction of zinc oxide and eugenol has been studied by many investigators $32,33,34,35,36$. The setting reaction of zinc oxide-eugenol involves both a physical and chemical processes. Copeland et al. 34 points out that the set cement resulting from mixes of zinc oxide and 
eugenol consists of zinc oxide embedded in a matrix of long, sheath-like crystals of zinc eugenolate. Since zinc is a bivalent element with a coordination number of four, it is likely to form a chelate. With eugenol having a replaceable hydrogen and a nearby donor in the oxygen of the ortho-methoxy group, the chelate formed here would show two molecules of eugenol and one molecule of zinc.

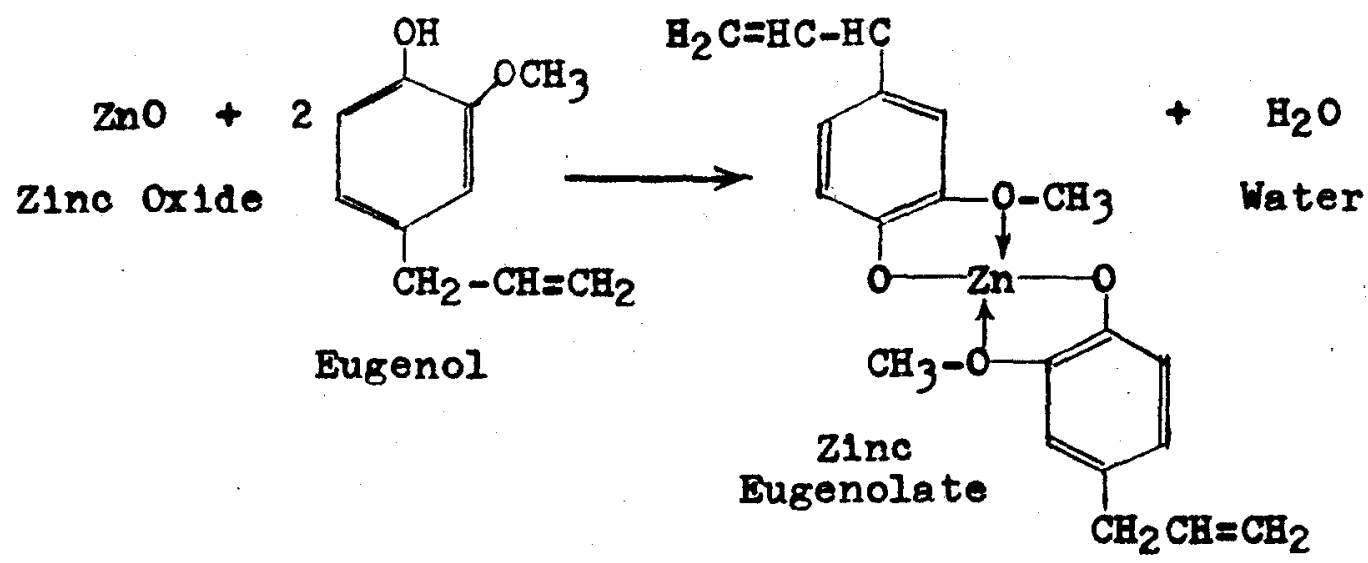

Upon seeing the setting reaction of zinc oxide and eugenol, one maj wonder how a set mass of the cement could contain an equimolar mixture. Most mixtures do not contain an equimolar mixture of zinc oxide and eugenol, and even if the mixture did contain such equal proportions, Copeland et al, 34 have shown through extraction procedures that there is unreacted zinc oxide as well as free eugenol. Their explanation from their findings is that the sheath-like $z$ inc eugenolate crystal act as atrix for the zinc oxide, and the excess eugenol is 
sorbed by the zinc eugenolate and possibly by the unreacted zinc oxide. In 1958. Smith ${ }^{35}$ demonstrated that during the setting reaction of the zinc oxide and eugenol cements, a concurrent sorption of eugenol took place. Hardening of the mixture is due to the zinc eugenolate formation while the unreacted eugenol that remained trapped tends to weaken the mass. And in 1967. Molnar 37 reported the progressive decrease in free eugenol in mixtures of 2 hours to 10 years. He also showed that the greater the amount of agltation, the less free eugenol was present.

Besides the studies performed on the nature of the setting reaction of zinc oxide and eugenol, many investigators have attempted to perfect the formula of the cement, whlle a considerable number of researchers studied the effects of add1tives to the basic mixture. Molnar and Skinner ${ }^{32}$ showed that zinc acetate and resin reduced the setting time. Weiss ${ }^{38}$ and Messing 39 indicated that the addition of polystyrene and zinc acetate would produce a cement which had a slow setting time and a high crushing strength. The strength of the cement can be highly increased by varlous additives such as polystyrene. hydrogenated rosin, and ortho-ethoxybenzoic acid (EBA) $32,38,39$. $41,43,44,45,46,47$.

There are many other factors which affect the setting time 
of zinc oxide and eucenol cement. Smith 40 found that the method of how the zinc oxide was prepared was closely related to its setting time. Wallace and Hansen 36 and others 35.41 .42 demonstrated that an increase in temperature and humidity during mixing resulted in a decrease in setting time. Smith 40 also made comment on the effect of the manner of spatulation as regards the setting time. He stated that the longer and more vigorously the mixture was spatulated, the greater the decrease in setting time. Norman et al. 43 demonstrated that the setting time of the cement was increased by decreasing the particle size of the zinc oxide.

\section{B. Boot Canal Cements or Sealers}

Today, the most commonly used root canal cements or sealers are the modified zinc oxide and eugenol mixtures. An Ideal root canal cement or sealer should fulfill the necessary requirements enumerated in the introduction of this peper, but as yet, none satisfies them all.

The mode of reaction in the setting of zinc oxide and eugenol is probably the mode of reaction in the setting of root canal sealers since zinc oxide and eugenol are the basic constituents. Through the use of various additives to the basic zinc oxide and eugenol, different authors have been able to vary the setting time, the solubility, the sealing property, 
the strength, and the dimensional stability of their preparations of a root canal sealer.

In the past two decades, the drive for a more scientific approach to endodontics have lead men to investigate the physlcal properties of root canal sealers. In 1954, seldier ${ }^{15}$ reported a great amount of shrinkage on setting of all the sealers, although he did not use any evidence to justify his observations. The following year McElroy 25 did a volume and a porosity study of nine sealers and their modifications. He concluded that the chloropercha combined with gutta-percha and Callahan's chloroform-rosin combined with gutta-percha had the greatest volume change: while Wach's filling material. Neobalsam, and Rickert's sealer demonstrated the least change in volume of those examined. In the porosity study, he found Wach's flling material to be least porous, and chloropercha to be the most porous.

The staining effect of the precipitated silver on tooth substance in both Rickert's $\mathrm{s}^{21}$ and Grossman's 22 root canal seglers prompted Grossman ${ }^{28}$ to develop a nonstaining cement which contalned zinc oxide, staybelite resin, bismuth subcarbonate, barlum sulphate, eugenol, and oll of sweet almond. The staybelite resin attributes adhesiveness. The bismuth subcarbonate gives it better radiopacity. The oll of sweet 
almond retards the setting time. There was no scientific data presented on the adhesiveness or the retardation of the setting time.

In 1958 , Stewart 48 did a study on the permeab111ty and tensile strength (or "adhesive property" as Higginbotham 50 describes 1t) of Diaket, the new Grossman sealer and the Kerr antiseotic pulp canal sealer. He concluded that there was no penetration by a test dye when Diaket was used. but that the new Grossman and Kerr sealers showed sealer-tooth interface penetrotion by the test aye to a depth of $0.5 \mathrm{~mm}$. While in another part of the study he showed Diaket to have the greatest tensile strength. In the tensile strength studies, he used orthodontic wires sealed in tubes. After the sealer was permitted to set for one week, scott tester was used to record the necessary pounds of pressure required to withdraw the wire from the tube.

Higginbotham 50 studied some of the physical properties of flve popular commerclal root canal sealers: setting time, film thlokness, solubility, radiopecity, and sealing abllity. Diaket. Tubl1-Seal, and Kerr sealer had about 21 to 23.5 minutes setting time, while no results were obtained for Proco-Sol and Kloroperka $N-\varnothing$. F1lm thickness varled from an average of 0.83 mm. for Tubl1-Seal to $0.433 \mathrm{~mm}$. for Diaket. The solubility of 
the materials in water for one week ranged from $0.11 \%$ (ProcoSol) to $0.72 \%$ (Kloroperka $\mathrm{N}-\varnothing$ ). The sesling abll1ty was determined by the use of radioactive 1sotopes, $\mathrm{Ca}^{45}$. The antiseptic pulp canal sealer and Proco-Sol showed better sealing properties at 1 month than at 1 day. It was belleved to be related to the slow setting time of the materials.

In 1965 and 1968, Curson and $\mathrm{K} 1 \mathrm{rk}^{51.52}$ tested different sealers for sealing ability, retentive strength, setting time. and working properties. The sealing abllity was tested ut1$11 z$ ing the dye penetration method. It was found that the fortified $z$ inc oxide and eugenol cement, Tubl1-Seal, Kerr Sealer, and AH-26 produced an excellent seal for the 30 day perlod. The strength test was studied using standard steel posts cemented into a standard size canal preparations. These vere separated on the tensometer after varying intervals. Fortified $z$ inc oxide and eugenol cement and Diaket strongly retained the posts. The setting time was determined according to the method of the American Denati Association specifications for dental cements. The materials were tested ory and with molsture to simulate a periapical situation. They showed that the more commonly used root canal sealers set in about two hours or less. and the addition of molsture decreased the setting time in most cases by one-half. They concluded that most sealers produced 
less satisfactory results after 30 days, although they felt that all the zinc oxide and eugenol cements and $A H-26$ were suitable root canal sealers.

Further studies on the comparative physical properties of Rlckert's sealer and the new Grossman sealer were conducted by Isasmend 153. He gudged the cement set when 1 t resisted penetration of the explorer point. At room temperature and humid1ty. Grossman's sealer set in three hours, and Rickert's sealer in twenty minutes. At $37^{\circ} \mathrm{C}$ in water. Grossman's sealer set in four hours, while Rickert's sealer set in 30 minutes. In testing the water absorption of the cements, he prepared mixes which set at normal room conditions. The samples were immersed in distilled water for 48 hours. He found Grossman's loss $2.78 \%$ of 1ts welgth, and Rickert's sealer $10830.99 \%$ of 1ts welght. He concluded that Rickert's sealer was superior to Grossman's in all respects.

In some of the most recent studies concerning the physical properties of root canal sealers. Weiner 54 investigated the setting time at varlous temperatures and relative humidities, and the dimensional changes after setting. In evaluating the setting time, the different mixes were subjected to nine combinations of environmental conditions. All of the specimens showed decreased setting time with increased temperature and 
relative humidity, with the exception of Proco-Sol Radiopaque Silver cement in a few of the test conditions where after three months the sealer was still unset. In the evaluation of the dimensional changes, the different sealer specimens were placed in glass micropipettes and visuel and photographic observation were made at varying intervals. After 90 days, Iinear dimensional changes were seen only in Kerr sealer, Tubli-Seal, and Roth 601. Volumetric loss was made by comparing the average volume change with the original volume calculated. The loss of volume increased with the increase of time. Kerr sealer was the only cement that did not show volume loss after 30 days whereas most sealers demonstrated a greater loss of volume after 30 days. Values for Proco-Sol nonstaining sealers were not obtained because the cement did not set completely in the pipette.

The use of radioactive 1sotopes have been utilized by many investigators $55,56.57 .58$ to study the sealing ability of the various root canal cements. Dow and Ingle 55 had concluded that poorly fllled root canals did not reveal leakage, and this could lead to an endodontic fallure. It may be concluded from the different studies using radionctive isotopes that the best seal is obtained when a well-fitted solid core was cemented with a zinc oxide and eugenol sealer. 
In 1970, Messing 59 used a high molecular welght fluorescent dye to study the sealing properties of chloropercha, Kerr sealer, AH-26, and silver amalgam in confunction with a solid core fllling materlal. A low molecular welght fluorescent dye was not used because it passed through the walls of the teeth and gave false positive reports. In all of the specimens, no dye penetrated into the dentin because of the high molecular weight. It was decided that the different methods and materlals used produced a hermetic seal without any penetration of the dye provided that a careful filling technic was followed.

Dentinal Response

One can conclude from a review of the ilterature, that there have been several investigations on the physical properties of root canal sealers, and numerous studies on connective tissue responses $7,8,12,52,53,56,57,65,66$ to these sealers. However, there have been few, if any, investigations relative to the effects of root canal sealers on dentin.

Dentin is a calcified connective tissue through which run dentinal fibers which usually are noncalcified. The dentinal fibers are protoplasmic processes of the cells that remain in the pulpal cavity. The mature dentin is composed of about $21 \%$ organic material and $67 \%$ inorganic material largely in the form 
of tricalcium phosphate. The root canal sealer used in a careful total obliteration of the pulpal space is in contact with sound dentin. Mjor 62 in 1962 studied the effects of $z$ inc oxide and eugenol on dentin in situ. First bicuspids which were to be extracted for orthodontic purposes were used in this study. He made preparations well into the dentin of several teeth, and covered the pulpal floor with a thick mixture of $z$ inc oxide and eugenol, then filled the rest of the preparation with amalgam. Some of the teeth were left unoperated as controls. Using the Kentron microhardness tester on the unpolished teeth section after varying intervals, he found a statistlcally significant increase (2.9 KHN) in the microhardness of the zinc oxide-eugenol covered dentin. It was felt that the increase in hardness was due to an increase in the mineralization of the dentinal tissue. Fusayama and Maeda 63 investigated the effect of pulpectomy on dentin of adult dogs. One of their findings was that no significant difference could be observed in the hardness of the dentin between the devitalized teeth with the pulp chambers left open and those obliterated with a zinc oxide and eugenol cement and a gutta-percha core. However, no details on the method of hardness testing was given. nor were the areas of dentin examined identified. To evaluste the effect of eugenol and root canal sealers 
containing eugenol on the microhardness of dentin, the methods of testing must be well described as well as the areas of dentin to be examined must be well delineated.

There have been a number of methods used to determine the hardness of tooth structure. Cra1g and Peyton 65 found that the microscratch or microindentation was the preferred method since the hardness of enamel and dentin has been shown to have large local varlations. The following year Craig, Gehring. and Peyton 66 undertook the study to correlate the microhardness of dentin with differences in structure. In this invest1gation, they stated that:

Measurements taken with the 10-gram load were found to show less experimental variation than those obtained with smaller loads and were considered to be more representative of microhardness values than those obtained with lesser loads because of the heterogeneous nature of dentin.

They used a 15-second time load cycle. The results of the study showed dentin adjacent to the root canals to be softer than the rest of the dentin, and the majority of the root dentin had the same microhardness as the dentin in the center of the crown. In studies by Craig et al. 66 and Peyton et al.67, 1t was emphasized that the Knoop hardness measurements were taken from the same teeth since the hardness of dentin is likely to vary considerably in similar areas in different teeth. And more 
precise data can be obtained from the same tooth in the adjacent areas of comparable indentation. Because of this highly heterogeneous nature of dentin, the comparative values reported by Mjor 62 of an increase of 2.9 KHN can hardly be statistically significant.

Rotberg and deshazer 64 in 1966 reported on the complexing action of eugenol on sound dentin. Rectangular samples of dentin were immersed in eugenol and in water. At periodic intervals, the samples were removed and the Iiquid phase was examined for calcium content. The comparative values were $21.5 \mathrm{mg} . / 100 \mathrm{ml}$. of calclum in the eugenol, and $2.8-4.1 \mathrm{mg} \cdot / 100 \mathrm{ml}$. of calclum in the distilled water. In another investigation of this study utilizing a von Kossa method of staining treated dentin to measure 1 ts calcium content, less calcium was found in the eugenol-treated samples than in the distilled watertreated samples. Samples treated with ethylenediaminetetracetic acid were devold of any stain, indicating that the calcium had been completely chelated. In the third portion of their experiment, their zinc oxide and eugenol mixtures were applied to dentin sections. Later, these mixtures were removed in toto from the dentin and the samples stained by the Glycoxal bis(2-hydroxynil) method of Kashiwa and Atkinson. The surface next to the dentin stained red, indicating calcium 
present, while the surface not exposed to the dentin did not stain at all. Rotberg and deshazer concluded that the "softening" of sound dentin beneath a zinc oxide and eugenol mixture might be explained by the complexing of the mixture with calcium. Since the more commonly used root canal cements or sealers are modifled zinc oxide and eugenol mixtures, it is suggested that some similar interaction may take place between the sound dentinal walls of the root canal and the sealer. Upon retreatment of an endodontic case, or in the case of a restorative procedure that is intimately connected with the core root canal filler, one not infrequently finds silver cones that are very loose. Does this mean that the complexing action of eugenol on sound dentin causes it to physically soften? With Rotbers and deshazer 64 pointing out the fact that eugenol has the ability to complex with calclum, and the fact that Molnar 37 . Copeland et al. 34 , and Smith 35 have shown that there is much free eugenol in zinc oxide and eugenol mixtures, it would seem appropriate to investigate the effect that eugenol and eugenol-containing root canal sealers have on sound human dentin. 
CHAPTER 3

\section{METHODS AND MATERIALS}

A. Selection and Preparation of Specimen

Freshly extracted mature permanent teeth were collected from the Oral Surgery Department, Loyola University School of Dentistry, Maywood. Illinols. The random selection of root specimens was completed on sufficiently large roots which demonstrated some hemorrhage or gelatinous pulp remnent in the canal upon sectioning. The specimens included samples of all types of teeth with the exception of mandibular centrals and laterals. These were not used because of their narrow mes10distal width. The fact that a tooth had either caries or restorations did not affect its selection for the experiment since only the midportion of the roots were utilized in the study.

Immediately upon the removal of these teeth, they were placed in sterile normal saline solution, and shortly thereafter the roots were sectioned horizontally, mldway between the cervical area and the apex of the tooth, using a high speed air rotor handpiece with water spray. The apical portions were 
used for the experiment. The sectioned surface of the root was left exposed while the rest of the root was embedded in Buehler plastic for cold mounting utilizing the Buehler Standard Specimen Mount Press*. The specimens were mounted to facilitate stabilization and easy handling during polishing and microhardness testing.

The resin mounted root specimens were polished on the Buehler Fine Grinding Apparatus* at low speed using emery polishing paper starting with grit \#1, then progressively to $0,00,000$, and finally effecting the final polish with 0000 . During the polishing, care was taken not to overheat the specimens. This was accomplished by applying the blocks to the polishing wheel for only short intervals and alternatingly dipping the specimen into room temperature distilled water. The face of the block was then dried with paper towel, and returned to the polishing wheel. At the conclusion of the polishing on the Buehler Fine Grinding Apparatus, the block was then refined on the Buehler Standard Metallographic polisher using a microcloth and a thin slurry of levigated alumIna (15 micron) and distilled water at $550 \mathrm{rpm}$. Th1s polishIng procedure resulted in an adequate surface for microhardness

*Buehler, Itd.. Evanston, IIl. 
testing. In the case where the specimen was to be treated with various sealers, a carefully prepared trough was placed around and contiguous with the tooth specimen using a \#4 round burr on the high speed handpiece. This procedure was initiated to prevent contact of the sealers with the resin block. A small round burr (\#2) was used to countersink into the root canal to simulate biomechanical preparation of the root canal. The act of countersinking into the root canal helped remove necrotic debris and also much of the predentin that is usually removed in root canal therapy.

B. Method of Microhardness Evaluation

The method ut1lized to evaluate the microhardness of the dentin was similar to that utilized by Craig et al. ${ }^{66}$ The Kentron micro hardness tester with the Knoop diamond indenter was used in this study. It was determined by Craig et al. 66 that a 10-gram losd exhlbited less experimental variation than measurements of smaller loads. They also employed a 15-second time load cycle in applying the knoop diamond indenter to the specimen of dentin.

Utilizing the 10-gram load at the 15-second time load cycle, 1t was necessary to view the indentations at 50X magnification for proper transcription. When measuring indentations, the 
makers of the Kentron micro hardness tester recommends that the objective used show a length of not less than 200 nor more than 700 fllar units. The $50 \mathrm{x}$ magnification satisfied this requirement. The ocular piece contained a filar micrometer for determining the filar units of the indentation. These filar units can be converted to microns by multiplying them by the factor of .2068. With this measurement in microns, reference is then made to standard tables prepared for each tester by the manufacturer that will in turn convert the measurement of each indentation to knoop hardness numbers.

Due to tre heterogeneous nature of dentin, it was decided that in order to acquire valid comparative measurements, they would be made as close as possible to each other, and yet not be influenced by adjacent marks. It was empirically determined that indentations to be compared side to side be made approximately three widths apart (approximately 40 microns). If the marks were compared length-wise, end to end, they were separated by not less than one indentation width. Initial indentations were placed approximately 200 microns from each other so as to provide sufficient margin for subsequent comparative microhardness measurements. 
C. Materials utilized to affect Sound Dentin

The following materials and preparations were selected

for study:
A. Eugenol, U.S.P.*
B. Root canal sealers
1. Proco-sol radiopaque silver cement**
Powder:
Preclpitated silver
Zinc oxide, U.S.P.
Hydrogenated resin
Magnesium oxide, U.S.P.

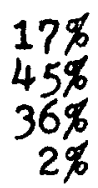

Liqu1d:

Eugenol

Canada balsam

2. Kerr pulp canal sealer***

Powder:

Zinc oxide (arsenic free) $34 \%$

silver (molecular) C.P. $25 \%$

oleo-resins

Dithymol dilodide

Liquid:

011 of cloves

Canada balsam

*The J. Bird Moyer Co., Inc., Philadelphia, Pa. **Proco-Sol Chemical Co.. Inc.. Philadelphia, Pa. ***Kerr Manufacturing Co.. Romulus, Mich. 
3. Wach's root canal sealer*

Powder:

Zinc oxide powder A.R. $184.0 \mathrm{gm}$.

Calcium phosphate tribasic $36.81 \mathrm{gm}$.

Bismuth subnitrate

Bismuth subiodide

Magnesium oxide, heavy

$64.41 \mathrm{gm}$.

$5.52 \mathrm{gm}$.

$9.21 \mathrm{gm}$.

Liquid:

Canada balsam

Clove oll, U.S.P.

Eucalyptol

Beechwood creosote
$222.00 \mathrm{cc}$. $66.66 \mathrm{cc}$. $5.67 \mathrm{cc}$. $5.67 \mathrm{cc}$.

D. Procedure for Determination of Microhardness Values

In all of the procedures involving the varlous root canal sealers, the following measures were pursued:

1. The use of a sterile and clean glass slab and spatula was utilized to $\mathrm{mix}$ the different materials.

2. The materials were mixed according to the recommendations of the manufacturers.

3. After the initial microhardness measurements, the specimens were abundantly covered with the sealers on the sectioned dentinal surfaces only.

4. The sealer covered specimens were stored in an analytical oven (low gradient)** at $37^{\circ} \mathrm{C}$ at approximately $90 \%$ relative humidity.

*KIng's Specialty Co., Fort Wayne, Ind. **Sargent-Welch Sclentific Co.. Chicago, Ill. 
5. After a three week interval, the specimens were removed from the oven, and the root canal sealers or cements were flicked off the dentinal surface with a \#23 dental explorer probing into the center of the root canal. In removing the bulk sealer. care was employed to avold marring the dentinal surface. The residue sealer was removed with $\mathrm{xyl}$ ol swabs and 1mmediately swabbed with $70 \%$ alcohol. The specimens were then dried with the air syringe.

6. Comparative microhardness readings were obtained from areas adjacent to the initlal measurements.

There were two root specimens used as controls in this study. They were mounted in a sample block and polished in the manner previously described. The specimens were placed in an analytical oven at $37^{\circ} \mathrm{C}$ at approximately $90 \%$ relative humldity for three days. This period permitted the specimen to adjust to the environment standard for the experiment. After wiping the sectioned surfaces with $70 \%$ alcohol, thirty-six initial microhardness readings were recorded. Twenty-one indentations were made on specimen \#1, and fifteen on \#2. The sample block containing the specimens were returned to the oven for a three week interval. The comparative microhardness measurements made on these control specimens were made adjacent to each other. 
Two resin blocks with three and four root specimens respectively were used for the eugenol treatment portion of the study. The teeth in this group were transected at mid root, and the sectioned coronal portion utilized in the study. The crowns of the teeth were embedded in the mounting resin with the spec1mens protruding approximately 5-7mm. Th1s arrangement prevented contact of the resin with the eugenol. The eugenol could have caused the mounting resin to dissolve. The specimens were polished and a total of 115 initial control indentations were made on the specimens, and then recorded. Each root specimen averaged 15 to 19 initial indentations. The surfaces of the specimens were then covered with a thin layer of fresh eugenol in a clean and sterile petri dish. The petri dish was placed In the oven for a predetermined interval.

After two and four weeks of contact in the eugenol, the speclmens were removed and wiped dry. The sectioned surfaces were washed with $70 \%$ alcohol and thoroughly drled with the air syringe. Microindentation measurements were made on the two week samples on the left and the four week on the right of the initial measurements.

In that part of the study concerned with the effect of Proco-Sol radiopaque silver cement, three root specimens were prepared in the usual manner and subjected to a total of 99 
initial hardness measurements. Each specimen received from 28 to 42 initial mea surements.

Subsequently a smooth and creamy mixture of one capsule of Proco-Sol cement powder and one drop of the Proco-Sol cement liquid was spatulated as recommended. A drop of the catalyst was added and thoroughly mixed with the cement. The mixture was applied to the dentinal surfaces of the exposed sectioned roots, care being exercised to restrict the cement to only the dentinal surfaces of the block. The sample block was then placed in the oven. After a three week interval (time period determined from the results of preliminary studies, page 34 ). the block was removed from the oven and the root canal cement removed from the specimens. Immediately thereafter, the specimens were swabbed with $70 \%$ alcohol, and comparative microhardness readings were recorded.

The three root specimens employed in the Kerr pulp canal sealer portion of the study recelved a total of 95 preliminary microhardness measurements; each of the specimens had from 22 to 45 initial readings. One capsule of Kerr pulp canal sealer powder was mixed with one drop of the required liquid to make a smooth and creamy mix. Generous amounts were placed over the sectioned surfaces of the specimens. The samples were stored in the oven at standard temperature and humidity, and at the 
end of a three week interval, they were removed and the sealer was cleaned from the specimens. Comparative microhardness measurements were made for each intial reading.

In the last portion of the study. Wach's root canal sealer was studied by the manner described above. A total of 74 initial microhardness measurements were recorded on three root specimens. One drop of the liquid was combined with sufficient powder to make a smooth and creamy "mix", which after spatulation, would string one inch from the glass slab to the spatula. The sealer was placed on the sectioned dentinal surface, and the specimens stored in the oren for the three weeks. Hence the hardened sealer was removed, and comparative microhardness measurements were obtained from areas adjacent to the initial readings. 
CHAPTER 4

\section{BESULTS}

In the preliminary studies with eugenol, it was found that the interaction between eugenol and human dentin as evaluated with the micro hardness tester attained a steady state of increased hardness at approximately three weeks. Values recorded after that time interval, up to six weeks, did not appear to fluctuate much desplte the weekly change of fresh eugenol. Furthermore, the sealers or cements hardened quite rigidly in less than three weeks while in the oven at the experimental conditions. Consequently, the three week interval was selected as the appropriate length of time required for this study.

The results obtained from the control root specimens showed a minimum change in microhardness values (Table 1 ). The mean of the 21 initial microhardness recordings of spec1men \#1 was $53.48 \mathrm{KHN}$ with a standard deviation of 8.19 . The mean of the 15 initial values of root specimen \#2 was 47.35 KHN with a standard deviation of 8.69 . The values obtained from root specimen \#1 after the three week interval demonstated 
TABLE 1

MEAN COMPARATIVE MICROHARDNESS DETERMINATIONS (KHN) CONTROL TEETH

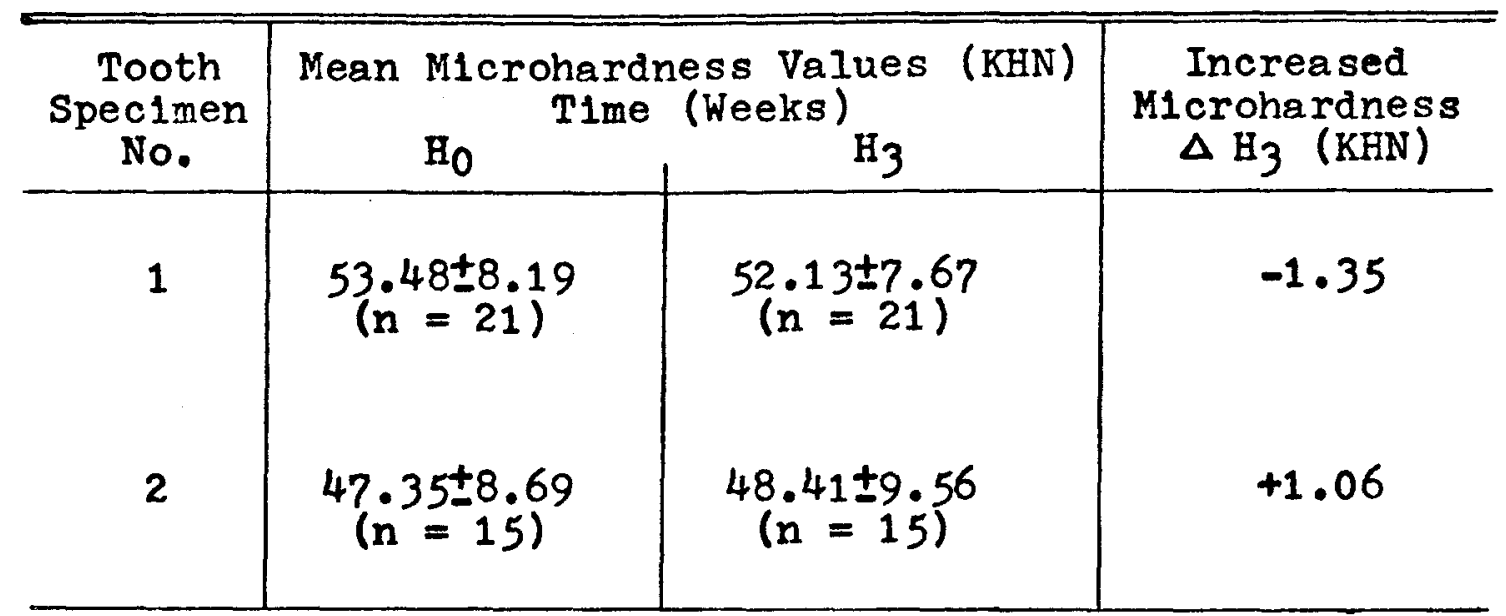


a mean of $52.13 \mathrm{KHN}$ and a standard deviation of 7.67 , thus showing a decrease in hardness of $1.35 \mathrm{KHN}$. Specimen \#2 demonstrated a slight increase in hardness of $1.06 \mathrm{KHN}$.

In the part of the study which involved the interaction of eugenol and the root dentin, seven root specimens were utilized. Typical rows of the microhardness values are shown in Table 2. The mean comparative microhardness determinations of each tooth specimen is shown in Table 3. The mean of the Initial recordings of all the specimens was $48.61 \mathrm{KHN}$ with a standard deviation 9.35. The mean value of all the specimens at the two week interval showed $58.83 \mathrm{KHN}$ with a standard deviation of 10.19. The mean value of all of the microhardness recordings at the four week interval was $60.37 \mathrm{KHN}$ with a standard deviation of 9.65 . These results are shown in Table 8 .

Table 4 demonstrates typical rows of microhardness values for Proco-Sol radiopaque silver cement. The results of this portion of the study are shown in Table 5. The results here demonstrated a vast increase in hardness of dentin after being in contact with the cement. The mean of the initial readings of specimen \#1 was $43.26 \mathrm{KHN}$ with a standard deviation of 7.54 , and this value increased to $50.40 \mathrm{KHN}$ with a standard deviation of 6.12 , thus yielding an increase of $7.14 \mathrm{KHN}$ in the difference of the means. Root specimen \#2 had a mean of $47.70 \mathrm{KHN}$ 
TABIE 2

TYPICAL ROWS OF MICROHARDNESS VALUES

EUGENOL

\begin{tabular}{|c|c|c|c|c|c|c|}
\hline \multirow[t]{2}{*}{ Row } & \multirow[t]{2}{*}{ Field } & \multicolumn{3}{|c|}{$\begin{array}{l}\text { Readings (KHN) } \\
\text { Time (Weeks) }\end{array}$} & \multicolumn{2}{|c|}{$\begin{array}{l}\text { Increased } \\
\text { Microhardness }\end{array}$} \\
\hline & & $\mathrm{H}_{\mathrm{O}}$ & $\mathrm{H}_{2}$ & $\mathrm{H}_{4}$ & $\Delta \mathrm{H}_{2}$ & v) $\triangle \mathrm{H}_{4}$ \\
\hline 1 & $\begin{array}{r}1 \\
2 \\
3 \\
4 \\
5 \\
6 \\
7 \\
8 \\
9 \\
10 \\
11 \\
12\end{array}$ & $\begin{array}{l}40.06 \\
45.70 \\
54.07 \\
47.38 \\
44.94 \\
44.94 \\
48.44 \\
38.24 \\
41.00 \\
37.02 \\
28.78 \\
28.78\end{array}$ & $\begin{array}{l}55.79 \\
62.80 \\
62.80 \\
63.87 \\
55.36 \\
56.24 \\
55.79 \\
41.20 \\
52.02 \\
51.23 \\
40.40 \\
31.51\end{array}$ & $\begin{array}{l}57.84 \\
66.30 \\
59.75 \\
63.87 \\
62.80 \\
58.78 \\
56.81 \\
54.49 \\
53.23 \\
49.60 \\
37.02 \\
37.02\end{array}$ & $\begin{array}{r}15.79 \\
17.10 \\
8.73 \\
16.49 \\
10.42 \\
17.86 \\
7.35 \\
2.96 \\
11.02 \\
14.21 \\
11.62 \\
2.73\end{array}$ & $\begin{array}{r}17.78 \\
20.60 \\
5.68 \\
16.49 \\
17.86 \\
13.84 \\
8.37 \\
16.25 \\
12.23 \\
12.58 \\
8.24 \\
8.24\end{array}$ \\
\hline 2 & $\begin{array}{l}1 \\
2 \\
3 \\
4 \\
5 \\
6\end{array}$ & $\begin{array}{l}43.39 \\
46.26 \\
36.90 \\
42.44 \\
55.36 \\
32.06\end{array}$ & $\begin{array}{l}75.54 \\
49.66 \\
55.36 \\
55.79 \\
62.80 \\
37.02\end{array}$ & $\begin{array}{l}71.85 \\
51.23 \\
57.61 \\
55.79 \\
65.24 \\
43.39\end{array}$ & $\begin{array}{r}32.15 \\
2.90 \\
18.46 \\
13.35 \\
7.44 \\
4.96\end{array}$ & $\begin{array}{r}28.46 \\
4.97 \\
20.71 \\
13.35 \\
6.88 \\
11.33\end{array}$ \\
\hline 3 & $\begin{array}{l}1 \\
2 \\
3 \\
4 \\
5\end{array}$ & $\begin{array}{l}67.54 \\
56.81 \\
49.16 \\
40.10 \\
54.49\end{array}$ & $\begin{array}{l}71.21 \\
62.80 \\
54.07 \\
63.87 \\
60.24\end{array}$ & $\begin{array}{l}74.17 \\
68.13 \\
60.24 \\
64.69 \\
68.73\end{array}$ & $\begin{array}{r}3.67 \\
5.99 \\
4.91 \\
23.77 \\
5.75\end{array}$ & $\begin{array}{r}6.63 \\
11.32 \\
11.08 \\
24.59 \\
14.24\end{array}$ \\
\hline
\end{tabular}


TABLE 3

MEAN COMPARATIVE MICROHARDNESS DETERMINATIONS (KHN) EUGENOL

\begin{tabular}{|c|c|c|c|c|c|}
\hline $\begin{array}{c}\text { Tooth } \\
\text { Specimen } \\
\text { No. }\end{array}$ & $\begin{array}{l}\text { Mean Micro } \\
\mathrm{H}_{0}\end{array}$ & $\begin{array}{c}\text { hardness Val } \\
\text { Ilme (Weeks) } \\
\mathrm{H}_{2}\end{array}$ & $\begin{array}{c}\text { es }(\mathrm{KHN}) \\
\mathrm{H}_{4}\end{array}$ & $\begin{array}{l}\quad \text { In } \\
\mathrm{Mlcr} \\
\Delta \mathrm{H}_{2}\end{array}$ & $\begin{array}{l}\text { ased } \\
\text { rdness } \\
\text { N) } \triangle \mathrm{H}_{4}\end{array}$ \\
\hline$(n=28)$ & $46.49 \pm 8.52$ & $58.30 \pm 9.34$ & $59.20 \pm 9.23$ & 11.80 & 12.70 \\
\hline$(n \stackrel{2}{=} 33)$ & $49.06 \pm 4.92$ & $63.45 \pm 4.97$ & $63.33 \pm 5.43$ & 14.39 & 14.27 \\
\hline$(n \stackrel{3}{=} 24)$ & $59.14 \pm 8.48$ & $75.74 \pm 9.12$ & $74.19 \pm 6.66$ & 16.60 & 15.05 \\
\hline$\left(n^{4}=17\right)$ & $48 \cdot 51 \pm 12 \cdot 52$ & $55.34 \pm 13.35$ & $59.66 \pm 11.61$ & 6.83 & 11.15 \\
\hline$(n \stackrel{5}{=} 6)$ & $43.43 \pm 6.07$ & $52.04 \pm 7.70$ & $52.43 \pm 7.29$ & 8.61 & 9.00 \\
\hline$(n=8)$ & $46.78^{+} \pm 12.22$ & $55.98 \pm 10.44$ & $61.51 \pm 9.33$ & 9.20 & 14.73 \\
\hline$(n=4)$ & $46.84 \pm 12.72$ & $50.96 \pm 16.42$ & $52.28 \pm 18.00$ & 4.12 & 5.44 \\
\hline
\end{tabular}


TABIE 4

TYPICAL BOWS OF MICROHARDNESS VALUES PROCO-SOL RADIOPAQUE SILVER CEMENT

\begin{tabular}{|c|c|c|c|c|}
\hline Row & Field & $\begin{array}{l}\text { Bead } \\
\text { Time } \\
\mathrm{H}_{0}\end{array}$ & $\begin{array}{l}\mathrm{KHN}) \\
\mathrm{Ks}) \\
\mathrm{H}_{3}\end{array}$ & $\begin{array}{c}\text { Increased } \\
\text { Microhardness } \\
\Delta \mathrm{H}_{3} \text { (KHN) }\end{array}$ \\
\hline 1 & $\begin{array}{l}1 \\
2 \\
3 \\
4 \\
5 \\
6\end{array}$ & $\begin{array}{l}49.16 \\
49.16 \\
53.23 \\
51.23 \\
45.70 \\
42.44\end{array}$ & $\begin{array}{l}56.24 \\
52.42 \\
59.75 \\
60.74 \\
54.49 \\
50.85\end{array}$ & $\begin{array}{l}7.08 \\
3.26 \\
6.52 \\
9.51 \\
8.79 \\
8.41\end{array}$ \\
\hline 2 & $\begin{array}{l}1 \\
2 \\
3 \\
4 \\
5 \\
6\end{array}$ & $\begin{array}{l}41.30 \\
58.31 \\
60.24 \\
44.30 \\
38.77 \\
32.47\end{array}$ & $\begin{array}{l}54.07 \\
62.80 \\
65.81 \\
63.87 \\
40.40 \\
41.84\end{array}$ & $\begin{array}{r}12.77 \\
4.49 \\
5.57 \\
19.57 \\
1.63 \\
9.37\end{array}$ \\
\hline 3 & $\begin{array}{l}1 \\
2 \\
3 \\
4 \\
5 \\
6 \\
7 \\
8\end{array}$ & $\begin{array}{l}34.85 \\
50.85 \\
31.32 \\
30.20 \\
36.19 \\
54.49 \\
55.79 \\
43.06\end{array}$ & $\begin{array}{l}42.74 \\
57.37 \\
37.50 \\
37.02 \\
41.00 \\
62.80 \\
62.28 \\
47.38\end{array}$ & $\begin{array}{l}7.89 \\
6.52 \\
6.18 \\
6.82 \\
4.81 \\
8.31 \\
6.49 \\
4.32\end{array}$ \\
\hline
\end{tabular}


TABLE 5

MEAN COMPARATIVE MICROHARDNESS DETERMINATIONS (KHN) PROCO-SOL RADIOPAQUE SILVER CEMENT

\begin{tabular}{c|c|c|c}
\hline $\begin{array}{c}\text { Tooth } \\
\text { Specimen } \\
\text { No. }\end{array}$ & \multicolumn{2}{|c|}{$\begin{array}{c}\text { Mean Microhardness Volues (KHN) } \\
\text { Time (Weeks) }\end{array}$} & $\begin{array}{c}\text { Increased } \\
\text { Microhardness } \\
\Delta \mathrm{H}_{3} \text { (KHN) }\end{array}$ \\
\hline \begin{tabular}{c|c}
1 \\
$(\mathrm{n}=27)$
\end{tabular} & $43.26 \pm 7.54$ & $50.40 \pm 6.12$ & +7.14 \\
2 & & & +6.78 \\
$(\mathrm{n}=41)$ & $47.70 \pm 7.55$ & $54.48 \pm 7.45$ & +6.37 \\
$(\mathrm{n}=29)$ & $45.94 \pm 9.53$ & $52.31 \pm 9.97$ & + \\
\hline
\end{tabular}


for the initial recordings with a standard deviation of 7.55 , and the mean comparative value three weeks later was $54.48 \mathrm{KHN}$ with a standard deviation of 7.45 , thus a resulting increase of $6.78 \mathrm{KHN}$. Meanwh1le, specimen \#3 had a mean value of 45.94 KHN and a standard deviation of 9.53 for its initial readings, and a mean three-week value of $52.31 \mathrm{KHN}$ with a standard deviation of 9.97 . thus an increase of $6.37 \mathrm{KHN}$.

Typical rows of mlcrohardness values for the segment of the investigation that employed Kerr pulp canal sealer are shown in Table 6 . This portion of the study revealed a demonstrable increase in microhardness values (Table 7). Columns 2 and 3 of Table 7 represent the mean comparative microhardness determinations in Knoop hardness numbers. The increases in hardness of each of the root specimens were found to be 8.91 KHN, $9.76 \mathrm{KHN}$, and $6.99 \mathrm{KHN}$ respectively.

In the last part of the study, Wach's root canal sealer was placed on three root specimens. The results of the 75 Inttial recordings gave a mean of 48.77 KHN with a standard deviation of 7.46 . The mean comparative three-week interval value was $51.35 \mathrm{kHN}$ with a standard devlation of 6.82 . The difference in hardness of the two means showed a somewhat smaller increase of $2.58 \mathrm{KHN}$. 
TABLE 6

TYPICAL ROWS OF MICROHARDNESS VALUES KERR ROOT CANAL SEALER

\begin{tabular}{c|c|cc|c}
\hline Row & Field & \multicolumn{2}{|c|}{$\begin{array}{c}\text { Readings (KHN) } \\
\text { T1me (Weeks) }\end{array}$} & $\begin{array}{c}\text { Increased } \\
\text { Microhardness } \\
\Delta \mathrm{H}_{3} \text { (KHN) }\end{array}$ \\
\hline \multirow{2}{*}{1} & 1 & Ho & H3 & 8.61 \\
& 2 & 44.62 & 53.23 & 7.47 \\
& 3 & 59.90 & 57.37 & 10.89 \\
& 4 & 54.92 & 65.81 & 13.21 \\
& 5 & 55.36 & 68.13 & 7.44 \\
& 6 & 41.00 & 47.73 & 6.73 \\
\hline \multirow{2}{*}{2} & 1 & 49.16 & 66.38 & 17.22 \\
& 2 & 54.49 & 64.69 & 10.20 \\
& 3 & 56.24 & 61.25 & 5.01 \\
& 4 & 54.07 & 63.87 & 9.80 \\
& 5 & 55.36 & 63.87 & 8.51 \\
& 6 & 50.85 & 61.25 & 10.04 \\
& 7 & 34.42 & 44.62 & 10.20 \\
\hline 3 & 1 & 61.86 & 69.96 & 8.10 \\
& 2 & 60.74 & 69.34 & 8.60 \\
& 3 & 58.31 & 66.38 & 8.07 \\
& 4 & 31.14 & 46.03 & 14.89 \\
& 5 & 26.10 & 40.70 & 14.60 \\
\hline
\end{tabular}




\section{TABLE 7}

MEAN COMPARATIVE MICROHARDNESS DETERMINATIONS (KHN) KERR ROOT CANAL SEALER

\begin{tabular}{c|c|c|c}
\hline $\begin{array}{c}\text { Tooth } \\
\text { specimen } \\
\text { No. }\end{array}$ & \multicolumn{2}{|c|}{$\begin{array}{c}\text { Mean Microhardness Values (KHN) } \\
\text { Time (Weeks) }\end{array}$} & $\begin{array}{c}\text { Increased } \\
\text { Microhardness } \\
\Delta \mathrm{H}_{3} \text { (KHN) }\end{array}$ \\
\hline $\begin{array}{l}1 \\
(\mathrm{n}=26)\end{array}$ & $49.29 \pm 7.09$ & $58.20 \pm 7.52$ & +8.91 \\
2 & $\mathrm{H}_{3}$ & & +9.76 \\
$(\mathrm{n}=44)$ & $48.03 \pm 9.12$ & $57.79 \pm 8.59$ & +6.99 \\
$(\mathrm{n}=22)$ & $52.26 \pm 5.17$ & $59.25 \pm 4.78$ & \\
\hline
\end{tabular}


A summary of the mean comparative microhardness values, In Knoop hardness numbers, of dentin due to the interaction of eugenol and eugenol-containing root canal sealers could be found in Table 8 .

The analysis of the results showed a statistically significant increase in the microhardness of human dentin when exposed to eugenol and eugenol-containing root canal sealers. The use of the t-test was employed to test the null hypothesis that the mean of the difference is equal to zero. At the $\alpha=0.01$ level, the results were statistically significant (see Table 9) 
TABLE 8

SUMMARY OF MEAN COMPARATIVE MICROHARDNESS VALUES (KHN) OF HUMAN DENTIN DUE TO EUGENOL AND EUGENOL-CONTA INING ROOT CANAL SEALERS*

\begin{tabular}{c|c|c|c|c|c}
\hline $\begin{array}{r}\text { Time } \\
\text { (Weeks) }\end{array}$ & $\begin{array}{c}\text { Eugenol } \\
100 \\
(n=120)\end{array}$ & $\begin{array}{c}\text { Proco-Sol } \\
\sim 90 \\
(n=97)\end{array}$ & $\begin{array}{c}\text { Kerr } \\
(n=78 \\
(n=92)\end{array}$ & $\begin{array}{c}\text { Wach's } \\
(n=74)\end{array}$ & $\begin{array}{c}\text { Control } \\
0 \\
(n=36)\end{array}$ \\
\hline 0 & $48.61 \pm 9.35$ & $45.63 \pm 8.21$ & $49.86 \pm 7.13$ & $48.77 \pm 7.46$ & $50.42 \pm 8.44$ \\
3 & $58.83 \pm 10.19$ & - & - & - & - \\
4 & $60.37 \pm 9.65$ & - & $58.41 \pm 6.96$ & $51.35 \pm 6.82$ & $50.27 \pm 8.62$ \\
\hline $\mathrm{H}_{3}$ & $\sim+11.00 * *$ & +6.77 & +8.55 & +2.58 & -0.15 \\
\hline
\end{tabular}

* Mean of the mean values of each tooth specimen.

* The mean value for a three week interval with eugenol was interpolated from the two and four week mean values. 
TABLE 9

STATISTICAL ANALYSIS UTILIZING THE $t$-TEST EVALUATION OF MICROHARDNESS INCREASE OF AFFECTED DENTIN

\begin{tabular}{c|c|c|c|c}
\hline $\begin{array}{c}\text { Material } \\
(n)\end{array}$ & $\begin{array}{c}\text { Mean* } \\
\Delta \mathrm{h}_{3}\end{array}$ & $\begin{array}{c}\text { Mean } \\
\Delta \mathrm{h}_{3} \\
\text { Control }\end{array}$ & t-Value & Probability \\
\hline $\begin{array}{c}\text { Eugenol } \\
(120)\end{array}$ & $11.53 \pm 5.94$ & $-0.37 \pm 3.44$ & 10.51 & $\mathrm{P}<.01$ \\
$\begin{array}{c}\text { Proco-Sol } \\
(97)\end{array}$ & $6.91 \pm 3.65$ & $-0.37 \pm 3.44$ & 12.37 & $\mathrm{P}<.01$ \\
$\begin{array}{c}\text { Kerr } \\
(92)\end{array}$ & $8.87 \pm 4.27$ & $-0.37 \pm 3.44$ & 13.53 & $\mathrm{P}<.01$ \\
$\begin{array}{c}\text { Wach's } \\
(74)\end{array}$ & $2.62 \pm 3.51$ & $-0.37 \pm 3.44$ & 6.66 & $\mathrm{P}<.01$ \\
\hline
\end{tabular}

* Mean of all the recordings of each group of specimens. 


\section{CHAPTER 5}

\section{DISCUSSION}

In 1966, Botberg and deShazer 64 observed a slight to moderate softening of sound dentin beneath clinically applied zinc oxide and eugenol mixtures in the preliminary work prior to their study of the action of eugenol on sound dentin. Although no scientific data was shown how the dentin was analyzed for softening. It would seem possible that loose particles of zinc oxide and eugenol on the dentinal surface mixed with molsture could have been mistaken for softened dentin. Further in their investigation, they showed the progressive removal of calcium from dentin. They employed the von Kossa staining technic for 1dentification of the relative amounts of calcium remaining in the various dentin sections after being treated with water, eugenol, and a $5 \%$ solution of disodium ethylenediaminetetracet1c acid (EDTA). They also utilized a modified spectrophotometric method for determination of calcium. The third method that they used to analyze for calclum was the Glycoxal bis(2-hydroxyn1l) method of Kashiwa and Atkinson. In their investigation, they demonstrated the ablilty of eugenol 
and zinc oxide-eugenol mixture to progressively remove calcium from dentin. They thought that the softening of sound dentin beneath a zinc oxide and eugenol mixture could be caused as a result of the ability of eugenol to complex with calclum. The results obtained in the present investigation disclosed an increase in the mlcrohardness of human dentin, which would be contrary to the findings of Rotberg and deshazer 64 if their use of the word "softening" was to indicate the decrease in hardness of dentin. But the present results would be consistent with the results of Mjör 62 which showed slight increase in microhardness of dentin due to the effect of zinc oxide-eugenol. It was shown by various invegtigators $34,35,37$ that there is much free eugenol avallable in zinc oxide and eugenol mixtures. The fact that there 18 a large amount of free or unreacted eugenol present in zinc oxide and eugenol mixtures over the period of years, leads to the premise that modifications of these mixes do contain much free eugenol. When root canal sealers that are basically $z$ inc oxide and eugenol mixtures are utilized in endodontics, these sealers do come in contact with dentin and probably interact w1th 1t. The results of this study positively indicate that with the increase of eugenol content in the various root canal sealers, there is a corresponding increase in microhardness of the dentin. This finding and an 
examination of the composition of root canal sealers; and in association with the results of $M j o ̈ r 62$ and Rotberg and deShazer 64 strongly suggest that eugenol is the material which brings about the changes in microhardness of dentin.

In his study of the effect of zinc oxide and eugenol on dentin in situ. Mjor 62 showed an average mean increase of 2.9 KHN. However, he compared entirely different teeth with each other and areas in the same teeth but remote from each other. The findings of Mjör 62 coincide with the assumption that dentin hardness is related to the viability of the dental pulp and its blologic response to cavity preparation and filling materials. The mineralization of the dentinal tubules in a viable tooth is a normal biologic response to various irritations. Nevertheless, Craig et al. 66 and Peyton et al. 67 emphasized that in order to obtain more precise data, comparable measurements must be taken in adjacent areas of the same fleld due to the highly heterogeneous nature of dentin. Hence, the comparative values reported by Mjör 62 can be consldered less than reliable. In demonstrating the variations in microhardness from areas adjacent to the pulp to areas in the vicinity of the cementum in transverse root sections, Craig et al. 66 showed values from 56 to $69 \mathrm{KHN}$ with a mean of $62 \mathrm{KHN}$. In a $2 \mathrm{~mm}$. distance with seven readings, it was readily apparent that a comparative 
reading be taken within $300 \mu$ of the initial reading for a significant value to be obtained. The comparative recordings acquired in the course of this present study were taken approximately 200 from each other. The findings of this investigation are in accord with those of Craig et a1.66.

From the results of Table 8 , the difference in hardness after three weeks shows Proco-Sol to be somewhat out of context in relation to the rest of the materials since its eugenol content is greater than that of Kerr, and yet 1 ts increase in hardness is slightly less. The most l1kely explanation for this slight deviation from a smooth curve would be a possibility of the different components of the various sealers as well as the particle size of the material. The reaction of the particular component with eugenol could be the factor which causes less eugenol to be free to interact with the dentin. The particle size of the material plays an important role. The smaller the particles in the mixture, the more surface will be avallable for the eugenol to react with and therefore less free eugenol will be avallable to interact with the dentin. Consequently, a conjecture could be made that if mixtures of liquids with increasing percentage of eugenol are mixed with equal amounts of a zinc oxide of uniform particle size, there would be a linear relationship between the gradual increase in micro- 
hardness values and the increasing percentage of eugenol content of the mixes as they interact with dentin.

The results obtained in the part of the study which involved Wach's root canal sealer showed a slight increase in microhardness. The average mean difference in hardness after three weeks demonstrated a $2.58 \mathrm{kHN}$. It would seem logical that the low increase in hardness would be consistant with the low percentage of eugenol in this sealer. The different microhardness readings had a wide variation. However, approximately $80 \%$ of the recordings showed a significant increase in microhardness values.

Some explanations for this increase in the microhardness values of dentin that have been exposed to eugenol and eugenolcontalning root canal sealers would now be considered.

The structural nature of dentin consists mainly of odontoblastic processes within the dentinal tubules and intercellular substances of mineralized apatite crystals, hypomineralized areas, and varying amounts of organic elements and water. Dentin consists of $70 \%$ inorganic material and $30 \%$ organic matter and water. Therefore, in order to discuss the findings of this study, there must be some speculation of the action of eugenol and the root canal sealers that contain eugenol on either the organic or inorganic substances of dentin, or the combination 
of these materials.

A tentative explanation for the increased hardness of human dentin due to eugenol and eugenol-containing root canal sealers may be the effect of the eugenol on the organic portion of dentin. As shown in a previous study 64 , eugenol does have a complexing action with calcium, thereby removing calcium from dentin. This may be a secondary factor in the inducement of increased hardness of dentin. The primary factor may be the "coagulating" effect of eugenol on collagen. As mentioned before. mature dentin is composed of approximately $20 \%$ organic material. It would seem feasible that the eugenol-effect in tiates a high volumn loss of water from the dentin, and thereby altering the ratio of water to calclum. As the effect of eugenol further causes increase in "coagulation". there is a tendency for a state of equilibrium in concentration in acquiring more water to compensate for the increased amount of calcium. The calcium now tends to bind with the protein within the dentinal tubules and its interconnecting branches. Furthermore, with the number of tubules per square millimeter on the pulpal surface of dentin varying from 30,000 to 75,000 , It would seem possible for the calclum-protein salt formed to increase the remaining hydroxyapatite structure strength by forming a rigid lattice frame within the dentin. 
The increased hardness of dentin through the action of eugenol and eugenol-containing root canal sealers as a result of this study could also be interpreted as an effect caused by eugenic acid. Eugenic acld is a weak acld, but stronger than carbonic acid. The action of eugenic acid on the hydroxyapatite and uncalcified substances is possibly the breakdown of the calcium salts in such a manner that a loss of carbonates take place as eugenic acid replaces the weaker carbonic acid of dentin. With the loss of carbonates, there is a rise in the $\mathrm{pH}$, and thus remineralization or reprecipitation of minerals from the dissolved apatite takes place which in turn possibly creates a more rigid dentin. The reprecipitate could possibly occur peritubularly or within the dentinal tubules. The ldea of this weak eugenic acid reacting with dentin is consistent with the slow changes that take place as evaluated by microhardness testing.

How the increase in hardness of the dentin could affect the physical property of brittleness of the dentin could be speculated at this time. Dentin has a modulus of elasticity that varies with the age of the tooth. With the increase of calcification of the tooth, the relative amount of the inorganic component rises and the relative amount of the organic material decreases and there is a gradual loss of elasticity. The 
application of eugenol or eugenol-contalning root canal sealers to dentin increases the hardness of dentin. Whether this increase is due to the effect of eugenol on the organic materials of the dentin or the remineralization of the dentin caused by eugenic acid. 1t could be speculated that there may well be an increase in the brittleness of dentin under these clinical circumstances.

It has been reported by different investigators $68,69,70$ that there seems to be a fallure of zinc oxide and eugenol to produce a calcific bridge of secondary dentin at the site of pulp exposures. However, in dentin with near pulpal exposures, there is a mineralization in the viable tubules due to the normal biologic response of the odontoblastic processes to the irritation caused by the zinc oxide and eugenol. In the case of pulp exposures, the fallure of a calciflc bridge to form Indicates that the uncalcified avallable components for hydroxyapatite in the surrounding dentin binds with eugenol or the impurities of eugenol. This lack of calcification in the form of reparative dentin at the site of exposures points to the fact that there could be insufficient calcium present, and the "remineralization" of dentin overlying unexposed pulps is related to an overabundance of calcium and is rather a reprecipitation of this mineral. 
CHAPTER 6

\section{SUMMARY}

The use of root canal sealers or cements in conjunction with a rigid or plastic master point has become the most popular means of obliterating a root canal. There have been studles that have investigated the connective tissue response to these materials, and a few studies that have evaluated the physical properties of these materials. The effect of eugenol and several eugenol-containing root canal sealers on human dentin was analyzed by the microhardness testing in this study. Sound dentinal surfaces from the midsection of the roots of freshly extracted teeth were subjected to eugenol. Proco-sol radiopaque silver cement, Kerr pulp canal sealer, and Wach's root canal sealer for varying time intervals. Teeth used as controls were subjected only to the environmental conditions. and not to the various materials. The comparative microhardness readings of the control dentin did not show a significant difference in the experiment time period, whereas the dentin that had been exposed to eugenol, Proco-Sol, Kerr, and Wach's sealers demonstrated a statistically significant increase in microhardness values. 


\section{REFERENCES}

1. Ingle, J.J. Endodontics. Philadelphia: Lea \& Febiger, 1965. p. 201 .

2. Coolldge, E.D., and Kesel, R.G. Endodontology. Ph1ladelphia: Lee \& Febiger, 1956, 2nd ed., p. 242.

3. Healy, H.J. Endodontics. St. Lou1s: C.V. Mosby Company, 1960, p. 157 .

4. Luks, S. Pulp reactions to operative procedures. Dent. Clin. North America, July, 1963, p. 414.

5. Schilder, H. Filling root canals in three dimensions. Dent. Clin. North America, Nov., 1967, p. 724.

6. Grossman. L.I. Endodont1c Practice. Ph1ladelphia: Lea \& Febiger, 1966, 6th ed.. pp. 337-339, 353.

7. Dixon, C.M., and Rickert, U.G. Histological verification of results of root-canal therapy in experimental animals. J. Amer Dent Assn 25:1781-1803, 1938 .

8. Rappaport, H.M.; L1lly, G.E.; and Kapsimal1s, P. Toxicity of endodontic filling materials. Oral surg 18:785-802, 1964.

9. Sommer, R.F.; Ostrander, D.F.; and Crowley, M.C. Clinical Endodont1cs. Phlladelphia: W.B. Saunders, 1966, 3rd ed.. p. 195-196.

10. Ingle, J.I., and LeVine, M. Transactions of the Second International Conference on Endodontics. Philadelphia: University of Pennsylvania Press, 1958, p. 124.

11. Grossman, L.I. Transactions of the Second International Conference on Endodontics. Philadelphia: University of Pennsylvania Press, 1958, pp. 103, 144-155. 
12. Guttuso, J.; Mitchell, D.F.; and Healy, H.J. Histopathologic study of rat connective tissue responses to endodontic materials. I.A.D.R. $41: 60,1963$.

13. Coolldge, E.D., and Kesel, R.G. Endodontology.

Ph1ladelphia: Lea \& Febiger, 1956, 2nd.. pp.243-248.

14. Grossman, L.I. Transactions of the Th1rd International Conference on Endodont1cs. Philadelphia: University of Pennsylvania Press, 1963, p. 125.

15. Seidler. B. The technique and rationale of filling root canals. New York J Dent 24:376-385, 1954.

16. Haga, C.S. Microscopic measurements of root canal preparations following instrumentation. Northwestern University Bull. 52:2:11-19, 1967 .

17. Gutierrez, J.H., and Garcia, J. Microscoplc and macroscopic investigation on results of mechanical preparation of root canals. Oral surg 25:108-116, 1968.

18. Brady, E.P. Why do root canal fillings fall, and place us open to criticism? Dent Cosmos 62:1085-1087, 1920.

19. Grove, C.J. An accurate new technique for filling root canals to the dentino-cemental junction with impermeable materials. J. Amer Dent Assn 16:1594-1600, 1929.

20. Buckley, J.P. The pulpless tooth, 1ts pathology and conservation; a new method and technique of filling root canals. J. Amer Dent Assn 16:44-61, 1929.

21. Rickert, U.G., and Dixon, C.M. The control of root surgery Transactions 8th International Dental Congress. Paris, 1931. pp. 15-22.

22. Grossman, L.I. Filling root canals with silver points. Dent Cosmos 78:679-687, 1936 .

23. Schmitt, W. Zahnarztl. Welt, quoted in Grossman, I.I. Endodontic Practice. Philadelphia: Lea \& Febiger, 1966. 6th ed.. p.362. 
24. Waechter, R. Zahnaerztl. Welt, quoted in Grossman, L.I. Endodontic Practice. Philadelphia: Lea \& Febiger, 1966. 6th ed.. p.362.

25. McElroy, D.I. Physical properties of root canal materials. J. Amer Dent Assn 50:433-440, 1955.

26. McElroy, D.L., and Wach, E.C. Endodontic treatment with a zinc oxide-Canada balsam fllling materlal. J. Amer Dent Assn 56:801-806, 1958 .

27. Schroeder, A. Zahnaerztl. Welt u. Reform, quoted in Grossman, I.I. Endodontic Practice. Philadelphia: Lea \& Febiger, 1966, 6th ed., p. 362.

28. Grossman, L.I. An improved root canal cement. J. Amer Dent Assn 56:381-385, 1958 .

29. Nielson. T.H. The ability of 39 liquid chelating agents to form cements with metal oxides, respecting their usability as root-filling materials. Acta Odont Scand $21: 158-174,1963$.

30. Molnar, E.J. Cloves, oll of cloves and eugenol. The medico-dental history. Dent Items of Interest, Jun-Oct. 1942 .

31. Chrisholm, E.C. quoted in Braver, G.M. A review of zinc oxide-eugenol type filling materials and cements. Rev Belg Med Dent. 20:323-364, 1965.

32. Molnar, E.J., and Skinner, E.W. A study of zinc oxiderosin cements. 1. Some variables which affect the hardening time. J. Amer Dent Assn 29:744-751, 1942 .

33. Harvey, W., and Petch, N.J. Acceleration of the setting of zinc oxide cements. Brit Dent J 80:35-42, 1946.

34. Copeland, H.J.; Brauer, G.M.; Sweeney, W.T.; and Forziatti, A.F. Setting reaction of zinc oxide and eugenol. J Res Natl Bur. Stand. 55:133-138, 1955.

35. Smith, D.C. The setting of zinc oxide-eugenol mixtures. Brit Dent J 105:313-321, 1958 . 
36. Wallace, D.A., and Hansen, H.I. Zinc oxide-eugenol cements J. Amer Dent Assn 26:1536-1540, 1939 .

37. Molnar, E.J. Residual eugenol from zinc oxide-eugenol compounds. J D Res 46:645-649, 1967.

38. Welss, M.B. Improved zinc oxide and eugenol cement. Illinols Dent $J$ 27:261-271, 1958.

39. Messing, J.J. Polystyrene-fortifled zinc oxide-eugenol cement. Brit Dent J 110:95-100, 1961.

40. Smith, D.C. A quick setting zinc oxide-eugenol mixture. Brit Dent J 108:232, 1960 .

41. Coleman, J., and K1rk, E.E. An assessment of a modified zinc oxide-eugenol cement. Brit Dent J 118:482, 1965 .

42. Myers, G.E. Environmental factors and the physical properties of zinc oxide impression pastes. J Dent Res 40:775. 1961.

43. Norman, R.D.: Ph1ll1ps, R.W.; Swartz, M.L.; and Frankiewicz, T. The effect of particle size on the physical properties of zinc oxide-eugenol mixtures. J. Dent Res 43: $252-262,1964$.

44. Phillips, R.W., and Love, D.R. Effects of certain gdditive agents on the physical properties of zinc oxide-eugenol mixtures. J. Dent Res 40:294-303, 1961.

45. Brauer, G.M.; Simon, L.; and Sanguemano, L.D. Improved zinc oxide-eugenol type cements. J Dent Res 41:10961102,1962 .

46. Civjan, S., and Brauer, G.M. Physical properties of cements based on zinc oxide, hydrogenated rosin, o-ethoxybenzoic ac1d and eugenol. J Dent Res 43:289-299, 1964 .

47. Anderson, J.R., and Myers, C.E. Physical properties of some zinc oxide-eugenol cements. J Dent Res 45:379-386, 1966. 
48. Stewart, G.G. Comparative study of three root canal sealing agents. Oral Surg 11:1029-1041, 1174-1178, 1958 .

49. Erausquin, J., and Muruzabal, M. Tissue reaction to root canal cements in the rat molar. Oral Surg 26:360-373. 1968.

50. H1gginbotham, T.I. A comparat1ve study of the physical properties of five commonly used root canal sealers. Oral Surg 24:89-101, 1967.

51. Curson, I., and K1rk, E.E.J. A comparison of the properties of some root canal sealers. J Dent Res 44:1161,1965 (abstract).

52. Curson, I., and K1rk, E.E.J. An assessment of root canalsealing cements. Oral Surg $26: 229-236,1968$.

53. Isasmend1, F.A. Etude comparative des ciments de Rickert et de Grossman. Bev Franc Odontostomat 14:1187-1196. 1967.

54. Wiener, B.H. A comparative study of important physical properties of various root canal sealers. Thesis, Boston University, 1969.

55. Dow. P.R., and Ingle. J.I. Isotope determination of root canal fallure. Oral surg 8:1100-1104, 1955.

56. Marshall, F.J., and Massler, M. The sealing of pulpless teeth evaluated with radioisotopes. J Dent Med 16:172 184, 1961.

57. Kapsimalis, P.; Summitt, N.J.; and Evans, R. Sealing properties of endodontic filling materials using radioactive polar and nonpolar isotopes. Oral Surg $22: 386-$ 393, 1966.

58. Talim, S.T., and Igbal, S. Sealing of root canal fillings in vivo conditions as assessed by radioactive iodine. $\mathrm{J}$ Indian Dent Assn 39:198-202, 1967.

59. Messing. J.J. An investigation of the sealing properties of some root filing materials. J Brit Endodont Soc $4: 18-22,1970$ 
60. Hunter, H.A. The effect of gutta percha, sliver points, and Rickert's root sealer on bone healing. J Canad Dent Assn 23:385-388, 1957 .

61. Guttuso, J. H1stopathological study of rat connective tissue responses to endodontic materials. Oral Surg $16: 713-727,1963$.

62. Mjör, I.A. The effect of zinc oxide and eugenol on dentine evaluated by microhardness testing. Arch Oral Biol $7: 333-336,1962$.

63. Fusayama, T.. and Maeda, T. Effects of pulpectomy on dentin hardness. J Dent Res 49:684, 1970 (abstract).

64. Rotberg, S.J., and deShazer, D.O. The complexing action of eugenol on sound dentin. J Dent Res 45:307-310, 1966.

65. Craig, R.G., and Peyton, F.A. The microhardness of enamel and dentin. J Dent Res 37:661-668, 1958.

66. Craig, R.G.: Gehring, P.E.; and Peyton, F.A. Relation of structure to the microhardness of human dentin. J Dent Res $38: 624-630,1959$.

67. Peyton, F.A.; Mahler, D.B.; and Hershenov, B. Physical properties of dentin. J Dent Res 31:366-370, 1952 .

68. Nyborg, H. Healing processes in the pulp on capping. Acta Odont Scand 13:1-127, 1955.

69. Murphy, J.M., and Salviolo, J.A. Pulp conservation followIng carious exposures. New York J Dent 15:83-89, 1949.

70. Mohammed, Y.R.; Van Huysen, G.; and Boyd, D.A. Fllling bese materials and the unexposed and exposed tooth pulp. J Pros Dent 10:961, 1960. 


\section{APPROVAL SHEET}

The thesis submitted by Dr. Glenn M. Biven has been read and approved by members of the Department of Oral Blology.

The final coples have been examined by the director of the thesis and the signature which appears below verifies the fact that any necessary changes have been incorporated. and that the thesis is now given final approval with reference to content, form, and mechanical accuracy.

The thesis is, therefore, accepted in partial fulfillment of the requirement for the degree of Master of Science.
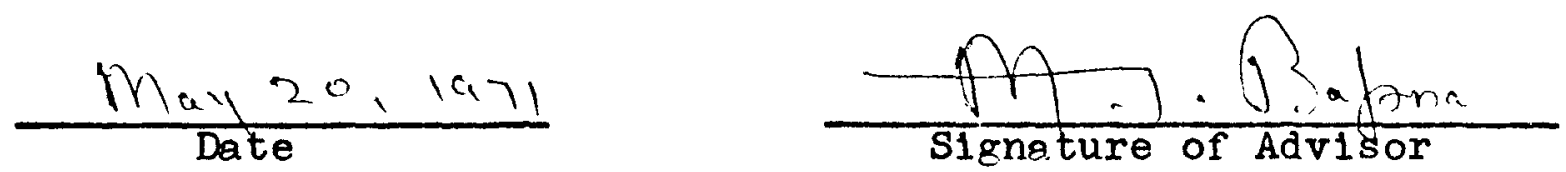